\title{
Genetic control of feeding preference in the herbivorous amphipod Ampithoe longimana
}

\author{
Erik E. Sotka* \\ Stanford University, Hopkins Marine Station, Pacific Grove, California 93950, USA
}

\begin{abstract}
The feeding preferences of individuals within a single species of marine consumer can differ because of variation in ontogeny, physiological state and environmental conditions; yet genetic variation can also play a central (largely undescribed) role. This study describes the nature of the genetic inheritance of feeding preference in the herbivorous amphipod Ampithoe longimana. Two populations known to have strong feeding preference for the chemically rich seaweed Dictyota menstrualis (from North Carolina, USA) were crossed to an $\mathrm{F}_{2}$ generation with 2 populations known to have lower preference for the seaweed (i.e. from Connecticut and Massachusetts), and all parental and hybrid lines were assayed for their feeding preferences. $\mathrm{F}_{1}$ hybrids of $\mathrm{A}$. longimana populations with high and low $D$. menstrualis preference displayed preferences intermediate to both parental lines, and there were no persistent differences among sexes in the inheritance of $D$. menstrualis preference in the $F_{1}$ or $F_{2}$ generations. These results suggest that feeding preference for $D$. menstrualis is likely a polygenic trait inherited in a largely additive manner on autosomes. The presence of substantial polygenic control of feeding preference among this and perhaps other marine consumers suggests that the genetic potential for local adaptation of this trait may be more common than currently appreciated.
\end{abstract}

KEY WORDS: Feeding preferences - Seaweed-herbivore interactions - Quantitative genetics - Chemical defense . Ampithoe longimana $\cdot$ Dictyota menstrualis $\cdot$ Hybrid

Resale or republication not permitted

without written consent of the publisher

Marine consumers are often picky about the foods they eat, especially when their prey produce formidable arrays of chemical, nutritional and morphological deterrents. There is broad interest in understanding the forces influencing the evolution of these feeding preferences (see reviews in Horn 1989, Hay 1996, Choat \& Clements 1998, Duda \& Palumbi 1999, Targett \& Arnold 2001), in part because they play central roles in determining the structure of marine biotic communities (Lawrence 1975, Lubchenco \& Gaines 1981, Duffy $\&$ Hay 2000), in the evolution of specialization of small

*Email: erik.sotka@stanford.edu consumers to larger hosts (Hay \& Fenical 1988, Vermeij 1992), and in the coevolution of consumer and prey (Vermeij 1994).

A survey of this literature leaves 2 major impressions. The first is that the feeding preferences of most consumers do not vary substantially within a species; nearly all of these studies compare species rather than populations or sub-populations (cf. Denno \& McClure 1983, Bernays \& Chapman 1994). The second impression is that where variation in feeding preference within a single species of consumer is documented, the variation is largely environmentally or ontogenetically induced, rather than being the consequence of genetic differences (e.g. Palmer 1984, Moran \& Arrontes 1990, Trowbridge 1991, Cronin \& Hay 1996, Rovero et al. 1999). These patterns may reflect the reality for most marine consumers, or, there may be a substantial, but largely unrecognized, genetic component to the variation in feeding preferences found within some marine consumers.

The lack of information on the genetics of feeding preference among marine consumers is surprising, given that the genetic control underlying feeding preference provides a 'picture of evolutionary possibility' or constraint by influencing the course and the rate of future evolutionary trajectories (Via 1990). Further, since shifts to new hosts or prey items are commonly initiated by behavioral adaptations (Jaenike \& Holt 1991), understanding the nature of the genetic inheritance of feeding preferences can help predict the responses of local biotic communities to human-induced perturbations, such as when non-native prey and consumer species are introduced (Travis \& Futuyma 1993, Ruiz et al. 2000).

In this paper, I identify and describe the nature of the genetic control underlying the feeding preferences of the herbivorous amphipod Ampithoe longimana, a small crustacean (adults $<2 \mathrm{~cm}$ long) found in shallow waters of the northwest Atlantic Ocean. In North 
Carolina, USA, the amphipod is found on seaweeds from several taxonomic classes, but it prefers brown seaweeds of the tropical genus Dictyota; these seaweeds produce diterpene alcohols that deter most herbivores but have minimal effects on A. longimana (Hay et al. 1987, Duffy \& Hay 2000, Cruz-Rivera \& Hay 2001). As with most herbivores having broad distributions (see Strong et al. 1984), the geographic range of the amphipod extends beyond that of its preferred host plants. Dictyota species are rarely found northward of the North Carolina/Virginia border, while populations of $A$. longimana extend northward through at least the Gulf of Maine. In 2 recent studies, Sotka \& Hay (2002) and Sotka et al. (2003) found that populations of $A$. longimana sympatric with Dictyota had higher affinity for, and fitness on, Dictyota than did populations outside the seaweed's geographic endpoint. These population-level differences were mediated by genetic differences in the ability to tolerate diterpenoid-rich secondary metabolites produced by the seaweed (Sotka \& Hay 2002).

I take advantage of this population-level variation in feeding preference in order to begin to describe its genetic control. Two sets of populations that display high tolerance for Dictyota (i.e. from North Carolina) were crossed to an $\mathrm{F}_{2}$ generation with populations that had low tolerance (i.e. from Connecticut and Massachusetts), and all parental and hybrid lines were assayed for their feeding preferences. It would be difficult to predict the nature of this genetic control a priori, since the diversity of genetic mechanisms underlying feeding preferences among other herbivores ranges from being extremely complex to relatively simple (Bernays \& Chapman 1994).

Materials and methods. Populations of the amphipod Ampithoe longimana were collected from 4 highsalinity sites along the eastern coast of the USA: Westport Point, Massachusetts $\left(\mathrm{MA}_{i} 41^{\circ} 32^{\prime} \mathrm{N}, 71^{\circ} 05^{\prime} \mathrm{W}\right)$; Millstone, Connecticut ( $\mathrm{CT}^{\prime}$; $\left.1^{\circ} 16^{\prime} \mathrm{N}, 72^{\circ} 09^{\prime} \mathrm{W}\right)$; Morehead City, North Carolina (MHC; $34^{\circ} 41^{\prime} \mathrm{N}, 76^{\circ} 46^{\prime} \mathrm{W}$ ); and Wilmington, North Carolina (Wil ${ }^{\circ} 34^{\circ} 13^{\prime} \mathrm{N}$, $77^{\circ} 48^{\prime} \mathrm{W}$ ). The 2 northern sites (CT and MA) are $90 \mathrm{~km}$ apart, the 2 southern sites (MHC and Wil) are $110 \mathrm{~km}$ apart, and $\sim 900 \mathrm{~km}$ separate the 2 regions. Amphipods were collected from a variety of seaweed species that occur at all sites, primarily the brown seaweed Ectocarpus spp. and green ephemeral seaweeds (e.g. Enteromorpha spp. and Bryopsis spp.). Amphipods in North Carolina were never collected from Dictyota spp. or during times of the year when Dictyota is most abundant (i.e. warm summer months).

Approximately 100 to 200 individuals seeded our laboratory cultures, which were then allowed to interbreed for $4+$ generations before the present experiment began (see Sotka \& Hay 2002 for details). Nine to
12 virgin males and 12 to 13 virgin females from each site were placed into 1 of 8 breeding lines: pure lines of all 4 sites and sets of reciprocal $\mathrm{F}_{1}$ hybrids for $\mathrm{CT} / \mathrm{MHC}$ and MA/Wil pairs. A majority of these virgins (68\%) was raised on Dictyota menstrualis or D. ciliolata and the rest were raised on Enteromorpha for another experiment. Since survival on the Dictyota spp. was uniformly high, it is unlikely that selection dramatically altered genetic variation that occurs among the populations (survivorship of $\mathrm{CT}$ and MA populations = $86.8 \%$; of North Carolina populations $=87.7 \%$ ).

Offspring of these breeding lines were raised to maturity on Enteromorpha and Sargassum at room temperature and $\sim 30 \%$. Seawater in plastic tubs ( $\sim 21)$ was aerated constantly, changed every 2 to $4 \mathrm{~d}$ by pouring through a Nitex screen (mesh size $=500 \mu \mathrm{m}$ ) to prevent passage of cultured amphipods, and replaced with filtered seawater collected from Bogue Sound, NC. There was 1 tub per population, and seaweeds were added when needed. All seaweeds added to the cultures were bathed in freshwater for at least $2 \times 30 \mathrm{~s}$ intervals, which eliminated Ampithoe longimana (Holmlund et al. 1990). After approximately $4 \mathrm{wk}$, the amphipods were offered a feeding choice between preweighed pieces of tissue from Dictyota menstrualis and Ulva sp., a green seaweed not known to differ in palatability to any of these populations (Sotka \& Hay 2002). Pieces were removed from each plant, blotted dry, weighed to the nearest milligram, and then placed in separate plastic bowls filled with $\sim 200 \mathrm{ml}$ of seawater. Approximately $50 \mathrm{mg}( \pm 10 \%)$ wetmass of each seaweed was added to the choice assay, and 2 to 3 adult amphipods were placed into each feeding assay bowl. For each individual plant, a paired bowl with seaweeds but without amphipods acted as a control for autogenic changes in plant mass unrelated to amphipod feeding. Replicates were stopped after the amphipods had consumed at least half of one plant piece or when $72 \mathrm{~h}$ had elapsed, whichever came first. Plant pieces were reweighed, and the change in wet mass of each piece was scaled to reflect autogenic changes (see Sotka \& Hay 2002). Replicates were dropped from the subsequent analysis ( $\sim 5 \%$ of all replicates) if the amphipods died during the assay or if the total mass of plant eaten was minimal $(<10 \%)$. In order to quantify the feeding preference of an individual amphipod for Dictyota, the feeding rate on Dictyota was divided by the total feeding on Dictyota plus Ulva. Each breeding line was offered tissue from a single plant, allowing us to block by plant within ANOVA. All data used were normally distributed (Shapiro-Wilks $W$-test, $\mathrm{p}>0.05$ ) and homoscedastic (Bartlett's test, $\mathrm{p}>0.05$ ).

Because initial results suggested sex-linkage in the inheritance of Dictyota preference, the $\mathrm{F}_{1}$ generation from crosses between $\mathrm{CT}$ and MHC populations were 
allowed to breed for a month and Dictyota preference by the male and female offspring of $F_{1}$ hybrids $\left(F_{2}\right.$ generation) were assayed as before. The blocked 2-way ANOVA tested whether sex, male source, or their interaction could explain variation in Dictyota preference. The data were normally distributed (Shapiro-Wilks $W$-test, p > 0.05) and homoscedastic (Bartlett's test, $\mathrm{p}>0.05$ ).

I made no attempt to quantify variation in chemistry within or between plants using liquid chromotography or mass spectrometry. Instead, I minimized the possibility that within-species variation biased the results in several ways. First, I collected Dictyota plants from a shallow subtidal jetty where the plants are always submerged and exposed to low densities of small grazers; desiccation and high densities of grazers are known to alter levels of chemical defenses (Cronin \& Hay 1996a,b). Second, all plants were kept in running seawater at an ambient temperature for less than $24 \mathrm{~h}$ before the assays began. Finally, I ran feeding assays on
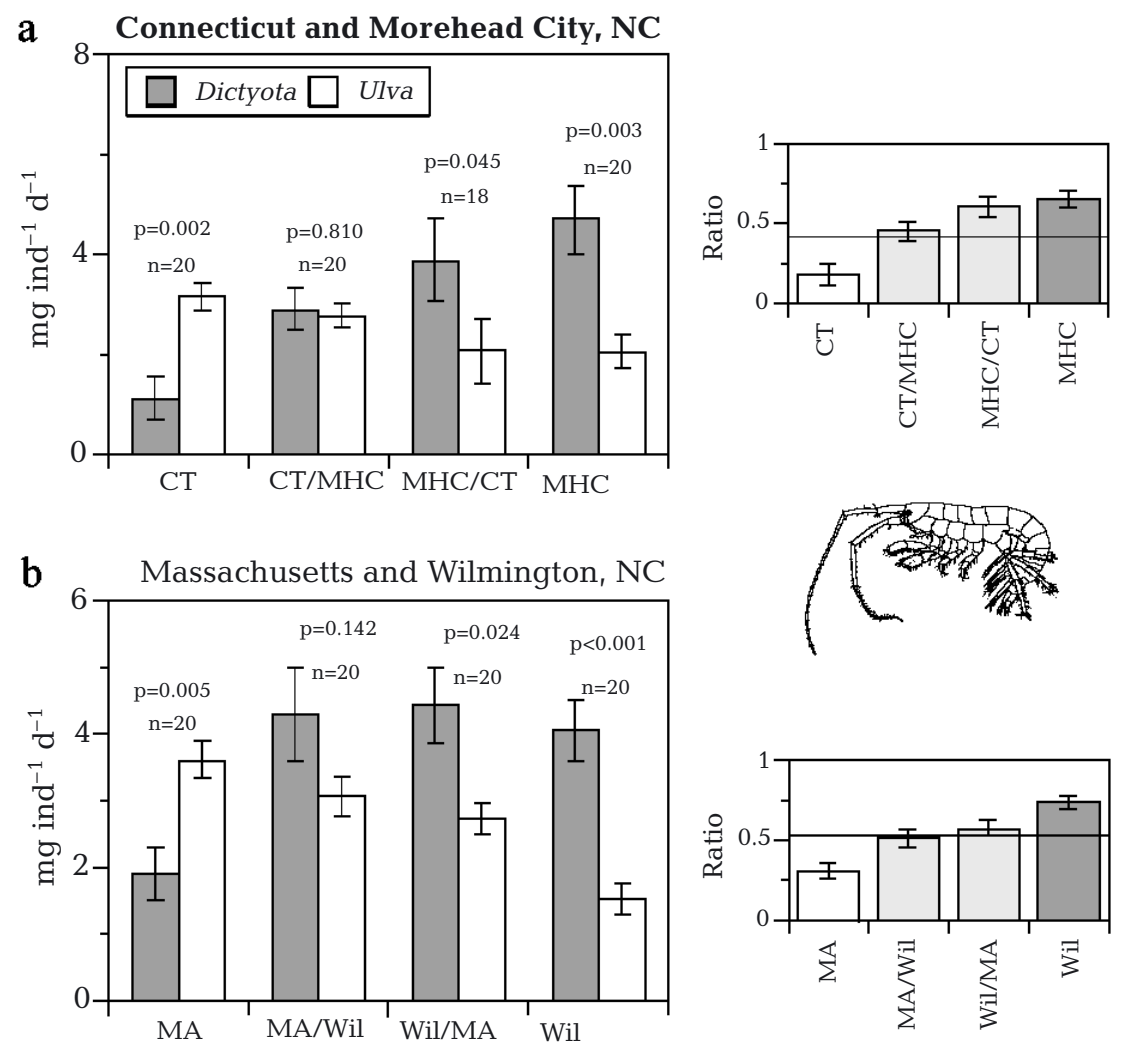

Fig. 1. Ampithoe longimana. Feeding preference for Dictyota exhibited by parental populations and their $F_{1}$ hybrids. (a) One set of hybrids created from Connecticut (CT) and Morehead City, NC (MHC) populations and (b) a second set created from Massachussetts (MA) and Wilmington, NC (Wil) populations. P-values are taken from paired $t$-tests. Two-way ANOVAs on Dictyota preference with male and female source as independent variables are shown in Table 1. For hybrids, the male source is given before female source (e.g. CT/MHC signifies CT males and MHC females). Right panels show ratios of feeding rate on Dictyota divided by total feeding on Dictyota and Ulva sets of breeding lines simultaneously (e.g. CT pure, MHC pure, and the 2 hybrid lines), which allowed me offer similar tissue from a single plant to each line. Thearly eliminated the possibility that either withining preference.

Results. The feeding preferences for Dictyota expressed by parental and $\mathrm{F}_{1}$ hybrid amphipods of northern (i.e. CT and MA) and southern populations (Wil and MHC) are presented in Fig. 1. CT individuals significantly preferred Ulva over Dictyota, while MHC ndividuals significantly preferred Dictyota over Ulva (Fig. 1a, left). Hybrids from Connecticut male and Moreead City female pairs (i.e. CT/MHC) ate Dictyota an Ulva at statistically indistinguishable rates, while hybrids from Morehead City male and Connecticut female pairs (i.e. MHC/CI) significantly preferred Dictyota. Intercasting like the MHC parental line, suggesting male linkage in the trait (Fig. 1a, right; Dictyota preference ratio halfway between means of parental lines $=0.427 ; \mathrm{MHC} / \mathrm{CT}$ mean $\pm \mathrm{SE}=0.617 \pm 0.070$ ), though no analogous difference was present with CT/MHC hybrid distribution and mean of parental lines (CT/MHC mean $\pm \mathrm{SE}=0.458 \pm 0.067$ ). A 2-way ANOVA on relative preference for Dictyota indicated that an interaction between male and female source was not significant (Table $1 ; \mathrm{p}=0.070$ ).

Crudely similar patterns were found with MA and Wil crosses (Fig. 1b). MA adults significantly preferred Ulva over Dictyota, while the Wil population significantly preferred Dictyota over Ulva. Hybrids from Massachusetts male and Wilmington female pairs (i.e. MA/Wil) ate Dictyota and Ulva at rates that could not be distinguished statistically, while hybrids from Wilmington male and Massachusetts female pairs (i.e. Wil/MA) significantly preferred Dictyota. No interaction between male and female source was detected by 2-way ANOVA (Table $1 ; p=0.693$ ), nor were there differences between either hybrid type and the mean preference of parental lines (Dictyota preference ratio halfway between means of parental lines = $0.521 ; \mathrm{MA} /$ Wil mean $\pm \mathrm{SE}=0.509 \pm$ $0.059 ;$ Wil/MA mean $\pm \mathrm{SE}=0.573 \pm$ 0.045). 
To confirm or refute the presence of male-linkage in the $\mathrm{MHC}$ and $\mathrm{CT}$ crosses, $F_{1}$ hybrids were left to interbreed for a month, and their $\mathrm{F}_{2}$ progeny were assayed for feeding preferences. Females from the MHC/CT crosses significantly preferred Dictyota; all other groups ate Dictyota and Ulva at rates that could not be distinguished statistically (Fig. 2). A direct test of relative consumption of Dictyota found no interaction among sex and source of male genetic material (Table 2). Thus, the suggestion from the $\mathrm{MHC} / \mathrm{CT}$ crosses that sex-linkage is present in this trait (Fig. 1a, Table 1) could not be confirmed using the Wil/MA crosses (Fig. 1b, Table 1) nor the $\mathrm{F}_{2}$ generation (Fig. 2, Table 2). Sex linkage in herbivore preference for host plants is known for a marine isopod (Jormalainen et al. 2001) and terrestrial insects (e.g. Thompson 1988); however, the present evidence suggests the effect in Ampithoe longimana, if any, is neither strong nor persistent.

Discussion. Recent studies documented that the herbivorous amphipod Ampithoe longimana held substantial genetic variation in its feeding preference for the seaweed Dictyota menstrualis. This was partitioned both within- and among-populations (Sotka \& Hay 2002, Sotka et al. 2003). The nature of the inheritance of the feeding preference was unknown. Here, a series of lab-based rearing and feeding assays determined that this polygenic trait is probably inherited in a largely additive manner on autosomes. $\mathrm{F}_{1}$ hybrids of A. longimana populations with high Dictyota preference (i.e. from North Carolina) and low Dictyota pref-
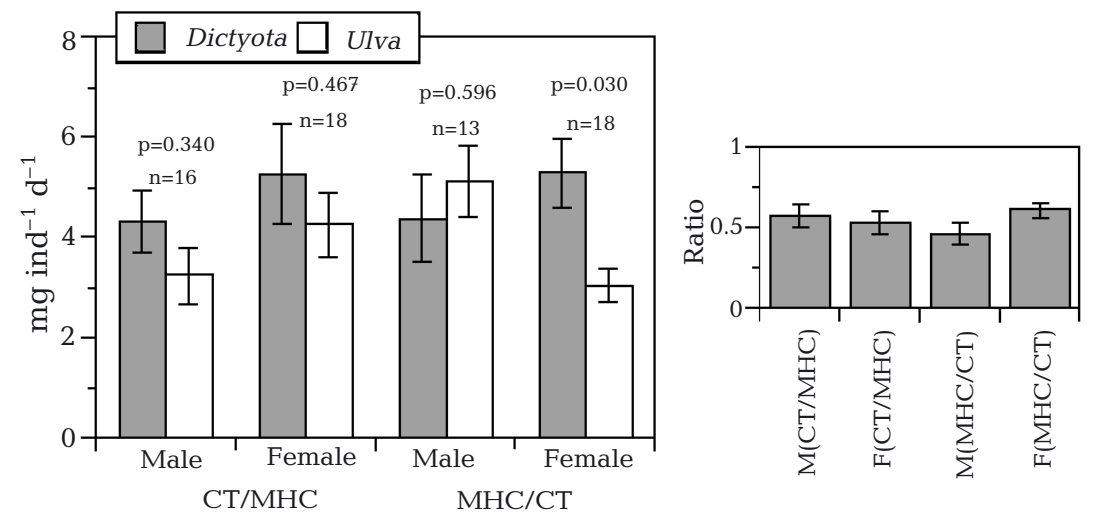

Fig. 2. Ampithoe longimana. Feeding preference for Dictyota exhibited by males (M) and females (F) of the Connecticut (CT) and Morehead City, NC (MHC) $\mathrm{F}_{2}$ hybrids. p-values are taken from paired $t$-tests. A 2-way ANOVA on Dictyota preference with sex and male source as independent variables is shown in Table 2. Right panel shows feeding rate on Dictyota divided by total feeding on Dictyota and Ulva erence (i.e. from Connecticut and Massachusetts) displayed Dictyota preferences intermediate to both parental lines (Fig. 1), indicating the additive nature of the trait. There were no persistent differences among sexes in the inheritance of Dictyota preference in the $F_{1}$ (Fig. 1) or $F_{2}$ generations (Fig. 2), suggesting that the trait is autosomally inherited, rather than sex-linked. Note that these effects are almost certainly genetic, since non-genetic effects were minimized; there were no previous exposures to Dictyota, and parents were taken from lab-based cultures maintained for 4+ generations.

For Ampithoe longimana, there may be an evolutionary consequence for the lowered preference for Dictyota among hybrids, relative to the North Carolina parental line. In North Carolina, A. longimana is one of few consumers that can tolerate Dictyota and its diterpene alcohols; other consumers are strongly deterred by the diterpene alcohols produced by the plant (Hay et al. 1987, Duffy \& Hay 1994, Stachowicz \& Hay 1999, Cruz-Rivera \& Hay 2003). As a consequence, a strong host preference for the chemically defended Dictyota provides A. longimana a refuge from omnivorous fishes. Sotka \& Hay (2002) indicate that, as a consequence of this selection, populations within the range of Dictyota have higher feeding preference for, and fitness on, Dictyota than do populations from outside the range of DiCtyota.

Since populations that are sympatric and allopatric with Dictyota may be exchanging migrants (Sotka et al. 2003), individuals from populations with low tolerance for Dictyota are potentially hybridizing with individuals from populations with higher tolerance for Dictyota, and vice versa. Because the Dictyota preferences of hybrids are lower than preferences of North Carolina genotypes, hybrids may not take advantage of the refuge provided 
Table 2. Ampithoe longimana. Two-way ANOVA on relative preference for Dictyota menstrualis using data from $\mathrm{F}_{2}$ hybrids of Connecticut (CT) and Morehead City, NC (MHC) populations. Source refers to the site from which the male parent orginated. Degrees of freedom (df), mean sums of squares (MS), F-ratios, and p-values are indicated

\begin{tabular}{|lrccc|}
\hline Source & df & MS & $F$ & $p$ \\
\hline Block & 9 & 0.129 & 2.43 & 0.036 \\
Sex & 1 & 0.095 & 1.79 & 0.192 \\
Male source & 1 & 0.006 & 0.10 & 0.750 \\
Sex $\times$ Male source & 1 & 0.090 & 1.69 & 0.204 \\
Error & 27 & 0.053 & & \\
\hline
\end{tabular}

by Dictyota, and could therefore become more susceptible to predation by omnivorous fishes (cf. Duffy \& Hay 1991, 1994). If such selection against hybrids is present, it could potentially impede the introgression of low-preference alleles into North Carolina populations, and help to maintain geographic differentiation in feeding behavior (Endler 1977, Barton \& Hewitt 1985). This hypothesis has a clear empirical test that will be pursued in the future.

Among other marine consumers, there are precious few data on the nature of inheritance of feeding preference. In the herbivorous amphipod Gammarus palustris, slight changes in the feeding preferences for the green seaweeds Ulva and Enteromorpha are correlated with allelic variation in a single digestive enzyme (Borowsky et al. 1985, Guarna \& Borowsky 1993, 1995), but it is clear that much of the phenotypic variation remains unexplained and is likely polygenic in origin. Another example may come from Peramphithoe parmerong, a marine amphipod that displays significant family-level variation in performance on Padina and Sargassum (Poore \& Steinberg 2001). If this variation in juvenile performance is mediated by their feeding behaviors, as it is for Ampithoe longimana (see Sotka \& Hay 2002), then one can infer genetic variation in the feeding preferences of P. parmerong. Third, preferences for different habitats (wood debris, Fucus distichus, or rhizomes of marsh grass) in the estuarine amphipod Eogammarus confervicolus are clearly under polygenic control (Stanhope et al. 1992), though it is unclear to what extent such habitat preferences reflect feeding preferences. Thus, several amphipod species, including $A$. longimana, display feeding preferences that are probably under polygenic control and, as such, each should be able to evolve local adaptations in preference. The fact that some (Stanhope et al. 1993, Sotka \& Hay 2002) but not all (e.g. Poore \& Steinberg 2001) of these species displayed local adaptation in behavior suggests that factors (e.g. environmental stability, strength of selection, gene flow) other than the nature of the genetic control may more strongly determine its evolution.
It remains to be seen whether such genetic variation in feeding preferences is commonplace among marine consumers. In the examples listed above, the detection of genetic variation required the use of small, shallowwater amphipods $(<2 \mathrm{~cm})$ that were raised for generations under controlled laboratory environments in a fairly short period of time (the generation time of A. longimana is $\sim 3 \mathrm{wk}$ ). I am not aware of unequivocal examples of genetic variation in feeding preference among larger consumers (e.g. fishes and urchins), in part because such questions are rarely asked. Instead, marine ecologists interested in within-species variation in feeding preferences of large (and small) consumers investigate the influences of ontogeny (e.g. Palmer 1984, Pennings 1990, Clements \& Choat 1993, Micheli 1997, Rovero et al. 1999, Muñoz \& Ojeda 2000), the consumers' recent history (e.g. Moran \& Arrontes 1990, Trowbridge 1991, 1997, Cronin \& Hay 1996, Thacker et al. 1997), prey availability (e.g. Pennings et al. 1993, Kennish et al. 1996), or prey quality (see Hay 1996 for review). Large consumers may or may not have substantial genetic variation in feeding preferences, but testing this will likely require the application of newer, molecular-based techniques to assess its extent (Ritland 2000, Thomas et al. 2000).

Acknowledgements. Funding was provided by a National Science Foundation Dissertation Improvement Grant (IBN0073073), American Museum of Natural History Lerner-Grey Memorial Fund for Marine Research, and a University of North Carolina at Chapel Hill-Paul Hardin Dissertation Completion Fellowship to E.E.S. Thanks go to N. Lindquist and R. Whitlatch for allowing me to invade their lab spaces and to 2 anonymous reviewers for comments.

\section{LITERATURE CITED}

Barton NH, Hewitt GM (1985) Analysis of hybrid zones. Annu Rev Ecol Syst 16:113-148

Bernays EA, Chapman RF (1994) Host-plant selection by phytophagous insects. Chapman \& Hall, New York

Borowsky R, Borowsky B, Milani H, Greenberg P (1985) Amylase variation in the salt marsh amphipod Gammarus palustris. Genetics 111:311-323

Choat JH, Clements KD (1998) Vertebrate herbivores in marine and terrestrial environments: a nutritional ecology perspective. Annu Rev Ecol Evol 29:375-403

Clements KD, Choat JH (1993) Influence of season, ontogeny and tide on the diet of the temperate marine herbivorous fish Odax pullus (Odacidae). Mar Biol 117:213-220

Cronin G, Hay ME (1996) Susceptibility to herbivores depends on recent history of both plant and animal. Ecology 77:1531-1543

Cruz-Rivera E, Hay ME (2001) Effects of macroalgal traits on the feeding and fitness of an herbivorous amphipod: the relative importance of selectivity, mixing, and compensation. Mar Ecol Prog Ser 218:249-266

Cruz-Rivera E, Hay ME (2003) Prey nutritional quality interacts with chemical defenses to affect consumer feeding and fitness. Ecol Monogr (in press)

Denno RF, McClure MS (1983) Variable plants and herbivores 
in natural and managed systems. Academic Press, New York

Duda TF, Palumbi SR (1999) Molecular genetics of ecological diversification: duplication and rapid evolution of toxin genes of the venomous gastropod Conus. Proc Natl Acad Sci 96:6820-6823

Duffy JE, Hay ME (1991) Food and shelter as determinants of food choice by an herbivorous marine amphipod. Ecology 72:1286-1298

Duffy JE, Hay ME (1994) Herbivore resistance to seaweed chemical defense: the roles of mobility and predation risk. Ecology 75:1304-1319

Duffy JE, Hay ME (2000) Strong impacts of grazing amphipods on the organization of a benthic community. Ecol Monogr 70:237-263

Endler JA (1977) Geographic variation, speciation, and clines. Princeton University Press, Princeton

Guarna MM, Borowsky RL (1993) Genetically controlled food preference: biochemical mechanisms. Proc Natl Acad Sci 90:5257-5261

Guarna MM, Borowsky RL (1995) Biochemical properties of amylase isozymes from Gammarus palustris. a comparative study. Comp Biochem Physiol 112b:619-628

Hay ME (1996) Marine chemical ecology: what's known and what's next? J Exp Mar Biol Ecol 200:103-134

Hay ME, Fenical W (1988) Marine plant-herbivore interactions: the ecology of chemical defense. Annu Rev Ecol Syst 19:111-145

Hay ME, Duffy JE, Pfister CA, Fenical W (1987) Chemical defense against different marine herbivores: are amphipods insect equivalents? Ecology 68:1567-1580

Holmlund MB, Peterson CH, Hay ME (1990) Does algal morphology affect amphipod susceptibility to fish predation? J Exp Mar Biol Ecol 139:65-83

Horn MH (1989) Biology of marine herbivorous fishes. Oceanogr Mar Biol Annu Rev 27:167-272

Jaenike J, Holt RD (1991) Genetic variation for habitat preference: evidence and explanations. Am Nat 137:S67-S90

Jormalainen V, Honkanen T, Mäkinen A, Hemmi A, Vesakoski O (2001) Why does herbivore sex matter? Sexual differences in utilization of Fucus vesiculosus by the isopod Idotea baltica. Oikos 93:77-86

Kennish R, Williams GA, Lee SY (1996) Algal seasonality on an exposed rocky shore in Hong Kong and the dietary implications for the herbivorous crab Grapsus albolineatus. Mar Biol 125:55-64

Lawrence JM (1975) On the relationships between marine plants and sea urchins. Oceanogr Mar Biol Annu Rev 13: 213-286

Lubchenco J, Gaines SD (1981) A unified approach to marine plant-herbivore interactions. I. Populations and communities. Annu Rev Ecol Syst 12:405-437

Micheli F (1997) Effects of experience on crab foraging in a mobile and a sedentary species. Anim Behav 53:1149-1159

Moran JAG, Arrontes J (1990) Factors affecting food preference in a widespread intertidal isopod. J Exp Mar Biol Ecol 182:111-121

Muñoz AA, Ojeda FP (2000) Ontogenetic changes in the diet of the herbivorous Scartichthys viridis in a rocky intertidal zone in central Chile. J Fish Biol 56:986-998

Palmer AR (1984) Prey selection by thaidid gastropods: some observational and experimental field tests of foraging models. Oecologia 62:162-172

Pennings SC (1990) Size-related shifts in herbivory: specialization in the sea hare Aplysia californica Cooper. J Exp Mar Biol Ecol 142:43-61

Pennings SC, Nadeau MT, Paul VJ (1993) Selectivity and growth of the generalist herbivore Dolabella auricularia feeding upon complementary resources. Ecology 74:879-890

Poore AGB, Steinberg PD (2001) Host plant adaptation in a herbivorous marine amphipod: genetic potential not realized in field populations. Evolution 55:68-80

Ritland K (2000) Marker-inferred relatedness as a tool for detecting heritability in nature. Mol Ecol 9:1195-1204

Rovero F, Hughes RN, Chelazzi G (1999) Effects of experience on predatory behaviour of dogwhelks. Anim Behav 57: 1241-1249

Ruiz GM, Fofonoff PW, Carlton JT, Wonham MJ, Hines AH (2000) Invasion of coastal marine communities in North America: apparent patterns, processes, and biases. Annu Rev Ecol Syst 31:481-531

Sotka EE, Hay ME (2002) Geographic variation among herbivore populations in tolerance for a chemically rich seaweed. Ecology 83:2721-2735

Sotka EE, Wares JP, Hay ME (2003) Geographic and genetic variation in feeding preference for chemically-defended seaweeds. Evolution (in press)

Stachowicz JJ, Hay ME (1999) Reducing predation through chemically mediated camouflage: indirect effects of plant defenses on herbivores. Ecology 80:495-509

Stanhope MJ, Leighton BJ, Hartwick B (1992) Polygenic control of habitat preference and its possible role in sympatric population subdivision in an estuarine crustacean. Heredity 69:279-288

Stanhope MJ, Hartwick B, Baillie D (1993) Molecular phylogeographic evidence for multiple shifts in habitat preference in the diversification of an amphipod species. Mol Ecol 2:99-112

Strong DR, Lawton JH, Southwodd SR (1984) Insects on plants: community patterns and mechanisms. Harvard University Press, Cambridge

Targett NM, Arnold TM (2001) Effects of secondary metabolites on digestion in marine herbivores. In: McClintock JB, Baker BJ (eds) Marine chemical ecology. CRC Press, Boca Raton, FL, p 391-412

Thacker RW, Nagle DG, Paul VJ (1997) Effects of repeated exposures to marine cyanobacterial secondary metabolites on feeding by juvenile rabbitfish and parrotfish. Mar Ecol Prog Ser 147:21-29

Thomas SC, Pemberton JM, Hill WG (2000) Estimating variance components in natural populations using inferred relationships. Heredity 84:427-436

Thompson JN (1988) Evolutionary genetics of oviposition preference in swallowtail butterflies. Evolution 42: 1223-1234

Travis J, Futuyma DJ (1993) Global change: lessons from and for evolutionary biology. In: Kareiva PM, Kingsolver JG, Huey RB (eds) Biotic interactions and global change. Sinauer Associates, Sunderland, MA, p 251-263

Trowbridge CD (1991) Diet specialization limits herbivorous sea slug's capacity to switch among food species. Ecology 72:1880-1888

Trowbridge CD (1997) Dietary induction of opistobranch morphology: Placida dendritica (Alder \& Hancock, 1843) on different green algal hosts. J Molluscan Stud 63:29-38

Vermeij GJ (1992) Time of origin and biogeographical history of specialized relationships between northern marine plants and herbivorous molluscs. Evolution 46:657-664

Vermeij GJ (1994) The evolutionary interaction among species: selection, escalation and coevolution. Annu Rev Ecol Syst 25:219-236

Via S (1990) Ecological genetics and host adaptation in herbivorous insects: the experimental study of evolution in natural and agricultural systems. Annu Rev Entomol 35:421-446 